\title{
Development of an alternative technology for the oyster mushroom production using liquid inoculum
}

\author{
Desenvolvimento de tecnologia alternativa para a produção de cogumelos ostra usando inóculo líquido
}

Márcia Luciane Lange SILVEIRA ${ }^{1 \star}$, Sandra Aparecida FURLAN ${ }^{1}$, Jorge Luiz NINOW ${ }^{2}$

\begin{abstract}
Pleurotus ostreatus, worldwide known as oyster mushroom, was cultivated in banana straw using inocula produced by two different processes - liquid inoculum and the traditionally used solid inoculum. Different ratios (5, 10, 15, and 20\%) were tested. Biological efficiency, yield, productivity, organic matter loss, and moisture of fruiting bodies as well as physical-chemical characteristics of banana straw were studied. Significant differences were observed for cellulose, lignin, and hemicellulose content between one and two harvests for both solid and liquid inocula. It was observed that $P$. ostreatus growth promoted higher degradation of lignin ( $80.36 \%)$, followed by hemicellulose (78.64\%) and cellulose (60.37\%). Significant differences between one and two harvests were also observed for the production parameters (biological efficiency and yield) for both kinds of inocula, liquid and solid. However, significant differences in productivity between harvests were observed only for solid inoculum.
\end{abstract}

Keywords: Pleurotus ostreatus; liquid inoculum; solid inoculum; inoculation ratio.

\section{Resumo}

Pleurotus ostreatus, conhecido mundialmente como cogumelo ostra, foi cultivado em palha de folha de bananeira, utilizando-se inóculos produzidos por dois processos diferentes: inóculo líquido e inóculo sólido usado tradicionalmente. Diferentes taxas de inoculação (5, 10, 15 e $20 \%$ ) foram testadas. Eficiência biológica, rendimento, produtividade, perda de matéria orgânica e umidade dos corpos frutíferos, como também as características físico-químicas da palha de folha de bananeira, foram estudadas. Diferenças significativas foram observadas para os teores de celulose, lignina e hemicelulose entre a primeira e segunda colheita, tanto para inóculo sólido quanto líquido. Foi observado que o cultivo de $P$. ostreatus proporcionou maior degradação de lignina (80,36\%), seguido de hemicelulose (78,64\%) e celulose (60,37\%). Diferenças significativas entre uma e duas colheitas também foram observadas para os parâmetros de produção (eficiência biológica e rendimento) para os dois tipos de inóculos, líquido e sólido. No entanto, diferenças significativas para produtividade entre uma e duas colheitas foram observadas somente para o inóculo sólido.

Palavras-chave: Pleurotus ostreatus; inóculo líquido; inóculo sólido; taxa de inoculação.

\section{Introduction}

Huge amount of waste is generated by the agricultural sector, forest exploitation, and food industries, which are chemically treated or sent to sanitary landfills. In the search for equilibrium between the social, economic, and environmental factors, the reuse of agricultural waste has taken on an extremely important dual purpose: elimination of the waste from the environment and giving it added value through the production of low cost food (VILLAS-BÔAS et al., 2002). One of the strategies developed for the disposal of large amounts of lignocellulosic waste is the production of edible mushrooms (CHANG; MILES, 1992). Recent studies have employed agricultural and forest waste to optimize biological, chemical, and physical parameters for mushrooms cultivation (LEIFA, 2002; CHAVES et al., 2004; FURLAN et al., 2006; GERN et al., 2007). In this context, the use of Pleurotus genus mushrooms constitute an important alternative for the reuse of lignocellulosic residues in Brazil (ABE et al., 1992; BONONI et al., 1995; SANTOS, 2000; SILVEIRA et al., 2006). Especially in the State of Santa Catarina it can be used in the bioconversion of banana residues, as it is one of the most important cultures in the state (IBGE, 2008).

Solid inoculum using wheat grain colonized by the fungal mycelium has been traditionally used for mushroom production (HESSELTINE, 1987; ABE et al., 1992; GUNDE-CIMERMAM, 1999). However, Chang and Miles (1993) stated that the replacement of solid by liquid inoculum could reduce laboratory cost and make the inoculation technique easier. According to Friel and McLoughlin (2000), the liquid inoculum can be used for the mycelium proliferation on solid support, or it can be directly inoculated in the production substrate. Considering that bioactive substances can be produced by Pleurotus in submerged cultivation, the mycelium biomass is a by-product that can be further used as inoculum for solid cultivation.

Based on the discussion above, the present work aimed to evaluate the production parameters of Pleurotus ostreatus fruiting bodies cultivated in banana straw, as well as to estimate the

Recebido para publicação em 4/7/2007

Aceito para publicação em 29/7/2008 (002629)

1 Universidade da Região de Joinville - UNIVILLE, Campus Universitário s/n, Bom Retiro, CEP 89223-251, Joinville - SC, Brasil, E-mail: sfurlan@univille.br

${ }^{2}$ Depatamento de Engenharia Química e Engenharia de Alimentos, Universidade Federal de Santa Catarina - UFSC, CEP 88040-900, Florianópolis - SC, Brasil

${ }^{*}$ A quem a correspondência deve ser enviada 
physical-chemical characteristics of the exhausted substrate, after cultivation using solid and liquid inocula.

\section{Materials and methods}

\subsection{Microorganism and maintenance}

Pleurotus ostreatus DSM 1833 was maintained in PDA (potato, dextrose, agar) medium, in Petri dishes, as described by Furlan et al. (1997), at $4^{\circ} \mathrm{C}$.

\subsection{Inoculum cultivated in solid medium}

Wheat grains were used as colonization support, growth substrate, and energy source. Polypropylene bags were prepared with $250 \mathrm{~g}$ of wheat grains, $1.3 \%(\mathrm{w} / \mathrm{w})$ calcium sulfate, and $0.35 \%(\mathrm{w} / \mathrm{w})$ calcium carbonate. The bags were closed, sterilized for 1 hour at $120^{\circ} \mathrm{C}$, cooled to room temperature, and inoculated with 3 agar disks ( $15 \mathrm{~mm}$ diameter) containing the mycelium of $P$. ostreatus removed from the Petri dishes. The bags were incubated at $30^{\circ} \mathrm{C}$ in the dark for 15 days or until complete colonization of the surface of the grains by the mycelium. The bags containing the "solid inoculum" were kept for 3 months at $4{ }^{\circ} \mathrm{C}$ for further use.

\subsection{Inoculum cultivated in liquid medium}

"Liquid inoculum" was obtained from submerged cultivation of P. ostreatus in POL medium $\left(5,0 \mathrm{~g} . \mathrm{L}^{-1}\left(\mathrm{NH}_{4}\right)_{2} \mathrm{SO}_{4} ; 0,2 \mathrm{~g} \cdot \mathrm{L}^{-1}\right.$ $\mathrm{MgSO}_{4} \cdot 7 \mathrm{H}_{2} \mathrm{O} ; 1,0$ g. $\mathrm{L}^{-1} \mathrm{~K}_{2} \mathrm{HPO}_{4} ; 2,0$ g.L. $\mathrm{L}^{-1}$ yeast extract; 1,0 g.L. $\mathrm{L}^{-1}$ peptone) using 40 g. $\mathrm{L}^{-1}$ glucose in a stirred tank reactor $\mathrm{MD}$ B. BRAUN with initial $\mathrm{K}_{\mathrm{L}}$ a equal to $15 \mathrm{~h}^{-1}, \mathrm{pH} 4.0$ and $30{ }^{\circ} \mathrm{C}$ (WISBECK et al., 2002). After 14 days of cultivation, the cell suspension was centrifuged and the mycelium was resuspended in $0.9 \%$ saline solution, transferred to Eppendorf tubes, and stored at $4{ }^{\circ} \mathrm{C}$ for further use.

\subsection{Culture medium and conditions}

Banana leaves were ground and then dried in an oven (SHELLAB - 1370FX) at $60^{\circ} \mathrm{C}$ for 1 hour and packed in raffia bags. The bags were submerged in water for 12 hours, as described by Madan et al. (1987). After eliminating the excess of water, the substrate was weighed, supplemented with $5 \%$ (on a dry weight basis) rice bran and transferred to polypropylene bags. These were then closed, sterilized in an autoclave (PHOENIX AV-137) for 1.5 hours, cooled to room temperature, and inoculated. For both kinds of inocula, solid and liquid, the following inoculation ratios were tested: $5,10,15$, and $20 \%$ of dry weight. The inoculated substrate was maintained at $25^{\circ} \mathrm{C}$ under light until total colonization with the fungal mycelium. The bags were transferred to the cultivation room for fruiting bodies production. Environmental conditions used in this step were: $27^{\circ} \mathrm{C}, 88 \%$ air humidity, and 12 hours of light per day. Primordia were induced by making small perforations in the bags. Fruiting bodies were harvested with a scalpel after 20 days of cultivation (STURION, 1994), weighed (METTLER- PM 4800 ), and dried in an oven (SHELLAB $-1370 \mathrm{FX}$ ) at $45^{\circ} \mathrm{C}$ for 24 hours. All experiments were carried out in octuplicate.

\subsection{Production parameters calculation}

Biological efficiency was calculated as proposed by Bisaria et al. (1987). Yield was determined as described by Chang et al. (1981), and productivity was obtained by the relationship between the fruiting bodies' dry weight and the cultivation time.

\subsection{Substrate composition analysis}

Samples of banana straw from all the bags representing the same inoculation ratio and the same harvest were mixed and dried at $105^{\circ} \mathrm{C}$. Substrate composition analyses were then performed in triplicate. The cellulose, hemicellulose, lignin, organic matter, digestibility, total digestible nutrients, and $\mathrm{pH}$ values were obtained according to Silva (1981). Total nitrogen, fiber, fat, and ashes were determined according to the A.O.A.C. (1984) methods.

\subsection{Statistical analysis}

All the parameters were analyzed by Dixon's "Q" test with $90 \%$ reliability $\left(\mathrm{r}_{10}\right)$, as proposed by Rorabacher (1991). The variance of the average values of the samples was calculated by the $F$ test, with a significance level of $1 \%$. For samples with significant differences, Duncan's test was used with a $1 \%$ confidence level.

\section{Results and discussion}

Table 1 presents the composition of banana straw in natura after supplementation and sterilization.

Based on the results presented in Table 1, banana straw is mostly composed of cellulose (53.45\%), followed by hemicellulose $(28.56 \%)$ and lignin (15.42\%). These values are in accordance with the literature (STURION, 1994; GHOSH et al., 1998). It can be seen that the substrate presents a low level of digestibility (15.40\%). The substrate composition changed after supplementation and sterilization, which according to Stölzer and Grabbe (1991), it may result from the release of sugar from the straw components after thermal treatment. On the other

Table 1. Composition of banana straw in natura after supplementation and sterilization.

\begin{tabular}{lcc}
\hline \multicolumn{1}{c}{ Parameter } & $\begin{array}{c}\text { In natura } \\
(\%)^{*}\end{array}$ & $\begin{array}{c}\text { Supplementation and } \\
\text { sterilization }(\%)^{*}\end{array}$ \\
\hline Hemicellulose $^{* *}$ & 28.56 & 21.82 \\
Cellulose $^{* *}$ & 53.45 & 52.79 \\
Ligninin $^{* *}$ & 15.42 & 12.27 \\
Digestibility $^{* *}$ & 15.40 & 13.00 \\
Total digestible nutrients $^{* *}$ & 16.20 & 12.00 \\
Organic matter $^{* *}$ & 95.50 & 92.30 \\
Total nitrogen $^{* *}$ & 6.02 & 8.52 \\
Total fiber $^{* *}$ & 28.54 & 27.89 \\
Total fat $^{* *}$ & 3.78 & 3.46 \\
Ashes $^{* *}$ & 6.77 & 6.97 \\
pH $^{* *}$ & 6.30 & 5.75
\end{tabular}

${ }^{*} \mathrm{~g} .100 \mathrm{~g}^{-1}$ dry matter; and ${ }^{* *}$ experiments were carried out in triplicates and average values are presented. 
hand, the nitrogen and ash levels increased due to the supplementation with rice bran.

After supplementation and sterilization, this substrate was tested for $P$. ostreatus growth using solid and liquid inocula at different ratios $(5,10,15$, and $20 \%)$. The analysis of the growth substrate showed significant differences in cellulose, lignin, and hemicellulose contents between the first and the second harvests for both kinds of inoculum. The same was observed for the fiber content for the solid inoculum.

It was found that Pleurotus growth promoted higher degradation of lignin $(80.36 \%)$, followed by hemicellulose $(78.64 \%)$ and cellulose $(60.37 \%)$, which agrees with the findings of Hadar et al. (1992) who cultivated the same species in cotton waste. These results were obtained with 10\% "liquid inoculum" after two harvests and proved higher than those reported in the literature (ORTEGA et al., 1992; BONATTI, 2001). According to Tuor et al. (1995), the higher or lower degradation of these components depends on the substrate supplementation, the fungal species, and the environmental conditions used for the cultivation.

A lower total fiber content (11.48\%) was obtained with 5\% solid inoculum after two harvests, which represents a decrease of $58.84 \%$ compared to the supplemented and sterilized straw. This reduction was higher than that observed by Ortega et al. (1992).

No significant difference was observed between solid and liquid inocula or first and second harvests for organic matter content, digestibility increase, nitrogen content, lipids content reduction, and ash content increase. For these parameters, the average values are presented below.

The organic matter content in the substrate decreased by $5.1 \%$ (average value) after $P$. ostreatus growth and fruiting bodies formation. As described by Rajarathnam and Bano (1989), this is due to $\mathrm{CO}_{2}$ and $\mathrm{H}_{2} \mathrm{O}$ loss during fungal metabolism, and, also to the elimination of some substrate materials in the production of fruiting bodies.
Digestibility increased by $185.7 \%$ (average value). This value is higher than that found by Zadrazil and Puniya (1995), but similar to that reported by Bonatti (2001). It was observed in this study that the digestibility was higher after the first harvest and decreased after the second in agreement with the results reported by Hadar et al. (1992) for Pleurotus spp. cultivated in cotton wastes. The average value obtained in this work for total digestible nutrients $(31.3 \%)$ is similar to that found by Bonatti (2001) for banana straw.

The average value for nitrogen content of the straw was $5.8 \%$, representing a $63 \%$ reduction compared to the supplemented and sterilized substrate. This value is higher than that reported by Bisaria et al. (1987) and Ortega et al. (1992).

The average value of lipids content reduction was found to be $69 \%$. The average value for ash $(10.10 \%)$ presented an increase of $63.8 \%$ when compared to the supplemented and sterilized straw. Similar data were obtained by Hadar et al. (1992) and Bonatti (2001). According to Sturion (1994), this is due to the use of the organic matter for fungi growth.

Table 2 presents the values of biological efficiency, yield, productivity, and moisture of $P$. ostreatus fruiting bodies cultivated in banana straw with solid and liquid inocula after one and two harvests.

The highest value of biological efficiency $(6.84 \%$ - after two harvests using $20 \%$ solid inoculum) is lower than that reported in the literature (CHANG et al., 1981; STURION, 1994; SANTOS, 2000) due to the number of harvests evaluated. In this study, we preferred to use only two harvests - even though this results in lower biological efficiency - due to the large loss of productivity when increasing the number of harvests (results not shown). While the average time needed for two harvests is between 46 and 51 days, about 100 days are necessary to obtain 4-5 harvests (STURION, 1994).

The highest yield value $(81.82 \%$ - after two harvests using $5 \%$ solid inoculum) is similar to that reported by Chang et al. (1981) and Sturion (1994) using only one harvest, but it is higher

Table 2. Biological efficiency, yield, productivity, and humidity of $P$. ostreatus fruiting bodies cultivated in banana straw with solid and liquid inocula after each harvest.

\begin{tabular}{|c|c|c|c|c|c|c|c|c|c|c|c|c|c|c|c|c|}
\hline \multirow[t]{2}{*}{ Parameter } & \multicolumn{4}{|c|}{$\begin{array}{c}\text { Solid inoculum - } \\
\text { one harvest }^{*}\end{array}$} & \multicolumn{4}{|c|}{$\begin{array}{l}\text { Liquid inoculum - } \\
\text { one harvest* }\end{array}$} & \multicolumn{4}{|c|}{$\begin{array}{l}\text { Solid inoculum - } \\
\text { two harvests }\end{array}$} & \multicolumn{4}{|c|}{$\begin{array}{l}\text { Liquid inoculum - } \\
\text { two harvests }\end{array}$} \\
\hline & $5 \%$ & $10 \%$ & $15 \%$ & $20 \%$ & $5 \%$ & $10 \%$ & $15 \%$ & $20 \%$ & $5 \%$ & $10 \%$ & $15 \%$ & $20 \%$ & $5 \%$ & $10 \%$ & $15 \%$ & $20 \%$ \\
\hline $\begin{array}{l}\text { Biological } \\
\text { efficiency } \\
\text { (\%) }\end{array}$ & $\begin{array}{l}3.75 \\
\text { a e h }\end{array}$ & $\begin{array}{c}4.08 \\
\text { a e g h }\end{array}$ & $\begin{array}{l}3.19 \\
\text { a e h }\end{array}$ & & & & & & & & $\begin{array}{c}5.55 \\
\text { a e g h }\end{array}$ & & & $\begin{array}{r}6.03 \\
\text { beh }\end{array}$ & $\begin{array}{l}6.41 \\
\text { be h }\end{array}$ & $\begin{array}{r}6.74 \\
\text { b e h }\end{array}$ \\
\hline $\begin{array}{l}\text { Yield } \\
(\%)\end{array}$ & $\begin{array}{l}48.03 \\
\text { a e g }\end{array}$ & $\begin{array}{l}46.67 \\
\text { a e g }\end{array}$ & $\begin{array}{l}40.45 \\
\text { a e h }\end{array}$ & & $\begin{array}{l}31.03 \\
\text { a e h }\end{array}$ & & & & & & & & & $\begin{array}{l}66.75 \\
\text { a e g }\end{array}$ & & $\begin{array}{r}65.26 \\
\text { a e g }\end{array}$ \\
\hline $\begin{array}{l}\text { Productivity } \\
\left(\mathrm{g} \mathrm{day}^{-1}\right)\end{array}$ & $\begin{array}{l}15.35 \\
\text { a e g }\end{array}$ & $\begin{array}{l}15,11 \\
\text { a e g }\end{array}$ & $\begin{array}{l}10.99 \\
\text { a e g }\end{array}$ & $\begin{array}{l}17.15 \\
\text { a f g }\end{array}$ & $\begin{array}{l}7.32 \\
\text { a e g }\end{array}$ & $\begin{array}{c}8.14 \\
\text { a e g h }\end{array}$ & $\begin{array}{l}11.60 \\
\text { a e g h }\end{array}$ & $\begin{array}{r}11.84 \\
\text { a e g h }\end{array}$ & $\begin{array}{l}22.00 \\
\text { a e g }\end{array}$ & $\begin{array}{l}19.59 \\
\text { a ef } g\end{array}$ & $\begin{array}{l}15.10 \\
\text { a ef } g\end{array}$ & $\begin{array}{l}20.20 \\
\text { a ef } f\end{array}$ & $\begin{array}{l}11.21 \\
\text { a f g h }\end{array}$ & $\begin{array}{l}13.24 \\
\text { a ef g h }\end{array}$ & $\begin{array}{l}15.12 \\
\text { a ef g h }\end{array}$ & $\begin{array}{l}17.30 \\
\text { a efh }\end{array}$ \\
\hline $\begin{array}{l}\text { Humidity } \\
(\%)\end{array}$ & $\begin{array}{l}91.73 \\
\text { a e g }\end{array}$ & $\begin{array}{l}89.28 \\
\text { a e g }\end{array}$ & $\begin{array}{l}92.31 \\
\text { a e g }\end{array}$ & $\begin{array}{l}90.59 \\
\text { a e g }\end{array}$ & $\begin{array}{l}91.35 \\
\text { a e g }\end{array}$ & $\begin{array}{l}90.77 \\
\text { a e g }\end{array}$ & $\begin{array}{l}88.86 \\
\text { a e g }\end{array}$ & $\begin{array}{c}86.45 \\
\text { a e g }\end{array}$ & $\begin{array}{l}89.51 \\
\text { a e g }\end{array}$ & $\begin{array}{l}89.03 \\
\text { a e g }\end{array}$ & $\begin{array}{l}91.87 \\
\text { a e g }\end{array}$ & $\begin{array}{l}91.17 \\
\text { a e g }\end{array}$ & $\begin{array}{l}89.19 \\
\text { a e g }\end{array}$ & $\begin{array}{l}90.06 \\
\text { a e g }\end{array}$ & $\begin{array}{l}89.95 \\
\text { a e g }\end{array}$ & $\begin{array}{r}85.83 \\
\text { a e g }\end{array}$ \\
\hline
\end{tabular}

$\mathrm{a}, \mathrm{b}, \mathrm{c}, \mathrm{d}=$ indicate the existence or not of significant differences in the production parameters between the different inoculation ratios for each kind of inoculum (analysis between columns of 5, 10, 15 and 20\%); e, $\mathrm{f}$ = indicate the existence or not of significant differences in the production parameters between the solid and liquid inocula for the same harvest (analysis between columns of solid and liquid inoculum for one harvest and between solid and liquid inoculum for two harvests); and $\mathrm{g}$, $\mathrm{h}=\mathrm{indicate}$ the existence or not of significant differences in the production parameters between one and two harvests for the same kind of inoculum (analysis between columns of solid inoculum for one harvest and two harvests and also for columns of liquid inoculum for one harvest and two harvests). 
than the values presented by Bonatti (2001). According to Bisaria et al. (1987), the yield of fruiting bodies varies with the kind of the substrate used, but there is no relationship between cellulose, hemicellulose, and lignin degradation and fruiting bodies yield. On the other hand, Rajarathnam and Bano (1989) consider that the higher capacity for lignocellulosic waste degradation implies a higher yield. This kind of relationship was not observed in our work: the highest degradation of cellulose and hemicellulose was observed with $10 \%$ liquid inoculum, while the highest yield was obtained with $5 \%$ solid inoculum, both after two harvests.

The highest productivity $\left(22 \mathrm{~g} \mathrm{day}^{-1}\right)$ was obtained with $5 \%$ solid inoculum after two harvests, and the average productivity was higher with solid inoculum than with liquid.

\section{Conclusions}

When the growth substrate was analyzed, significant differences were observed for cellulose, lignin, and hemicellulose contents between one and two harvests for both solid and liquid inocula. The total fiber content presented a significant difference for liquid inoculum after two harvests. It was observed that $P$. ostreatus growth promoted higher degradation of lignin (80.36\%), followed by hemicellulose $(78.64 \%)$ and cellulose $(60.37 \%)$. These values as well as the increase in digestibility obtained in this work are higher than those reported in the literature.

Significant differences between one and two harvests were observed for the production parameters of biological efficiency and yield for both kinds of inocula, liquid and solid. However, significant differences in productivity between harvests were observed only for solid inoculum.

Generally, significant differences were mostly observed between one and two harvests, but not between the inoculation ratios or between the two kinds of inocula. Therefore, it can be said that solid or liquid inocula can be used for the production of $P$. ostreatus fruiting bodies with $5 \%$ inoculation ratio, which is less expensive. The production parameters obtained under these conditions were: $6.84 \%$ biological efficiency, $81.82 \%$ yield, $22 \mathrm{~g}$ day $^{-1}$ productivity, $50.99 \%$ organic matter loss, and $92.31 \%$ humidity.

\section{Acknowledgements}

The authors are grateful for the financial support provided by the foundations FAP/UNIVILLE and CNPq/FUNCITEC and to Dr. Elisabeth Wisbeck for supplying the liquid inoculum.

\section{References}

ABE, E.; EIRA, A. F.; MINHONI, M. T. A. Relações entre temperatura de pasteurização e contaminação do composto durante o cultivo de Pleurotus ostreatus (Jacquim Fries) Kummer. Científica, v. 20, n. 2, p. 423-433, 1992.

A.O.A.C. Official Methods of Analysis of the Association of Analytical Chemists International. Arlington, 1984.

BISARIA, R.; MADAN, M.; BISARIA, V. S. Biological efficiency and nutritive value of Pleurotus sajor-caju cultivated on different agrowastes. Biological Wastes, v. 19, n. 4, p. 239-255, 1987.
BONATTI, M. Estudo do potencial nutricional de cogumelos do gênero Pleurotus cultivados em resíduos agro-industriais. Florianópolis, 2001. 148p. Dissertação - (Mestre em Engenharia Química), Departamento de Engenharia Química, Universidade Federal de Santa Catarina - UFSC.

BONONI, V. L.; CAPELARI, M.; MAZIERO, R. Cultivo de cogumelos comestíveis. São Paulo: Ícone, 1995.

CHANG, S. T.; MILES, P. G. Mushrooms: trends in production and technological development. Genetic Engineering and Biotechnology Monitor, v. 41/42, p. 73-81, 1993.

CHANG, S. T.; MILES, P. G. Recent trends in world production of cultivated edible mushrooms. Mushroom Journal, v. 504, p. 15-18, 1991.

CHANG, S. T.; LAU, O. W.; CHO, K. Y. The cultivation and nutritional value of Pleurotus sajor-caju. European Journal of Applied Microbiology and Biotechnology, v. 12, p. 58-62, 1981.

CHAVES, M. B. et al. Evaluation of Pleurotus ostreatus and Pleurotus sajor caju nutricional characteristics when cultivated in different lignocellulosic wastes. Food Chemistry, v. 88, n. 3, p. 425-428, 2004.

FRIEL, M. T.; McLOUGHLIN, A. J. Production of a liquid inoculum/ spawn of Agaricus bisporus. Biotechnology Letters, v. 22, n. 5, p. 351-354, 2000.

FURLAN, S. A.; GERN, R. M. M.; WISBECK, E.; BONATTI, M.; SILVEIRA, M. L. L.; SILVA, H. H. B. Possibilities of Pleurotus applications in food, health and environmental technologies. In: INTERNATIONAL CONGRESS ON BIOPROCESSES IN FOOD INDUSTRIES, 2006, Patras. Proccedings... Patras, Greece, p. 34-35, 2006.

FURLAN, S. A.; VIRMOND, L. J.; MIERS, D.; BONATTI, M.; GERN, R. M. M.; JONAS, R. Mushroom strains able to grow at high temperatures and low $\mathrm{pH}$ values. World Journal of Microbiology and Biotechnology, v. 13, p.689-692, 1997.

GERN, R. M. M.; WISBECK, E.; RAMPINELLI, J.; NINOW, J. L.; FURLAN, S. A. Alternative medium for production of Pleurotus ostreatus biomass and potential antitumor polysaccharides. Bioresource Technology, v. 99, p. 76-82, 2008.

GHOSH, M.; MUKHERJEE, R.; NANDI, B. Production of extracellular enzyme by two Pleurotus species using banana pseudostem biomass. Acta Biotechnologica, v. 18, n. 3, p. 243-254, 1998.

GUNDE-CIMERMAN, N. Medicinal value of the genus Pleurotus (Fr.) P. Karst. (agaricales s.l., Basidiomycetes). International Journal of Medicinal Mushroom, v. 1, n. 1, p. 69-80, 1999.

HADAR, Y.; KEREM, Z.; GORODECKI, B.; ARDON, O. Utilization of lignocellulosic waste by the edible mushroom, Pleurotus. Biodegradation, v. 3, n. 2-3, p. 189-205, 1992.

HESSELTINE, C. W. Solid state fermentation - an overview. International Biodeterioration, v. 23, n. 2, p. 79-89, 1987.

INSTITUTO BRASILEIRO DE GEOGRAFIA E ESTATÍTICA (IBGE). Disponível em: http://www.ibge.gov.br/estadosat/temas. $\mathrm{php} /$ sigla $=$ sc\&tema=lavourapermanente2006\&titulo=lavoura $\% 20$ permanente\%202006\%20. Acesso em: 21 fev. 2008.

LEIFA, F. Production of extra-cellular polysaccharide from Agaricus blasei by submerged and solid state culture and its antitumor effect. Curitiba, 2002. 123 p. Tese - (Doutorado em Processos Biotecnológicos), Departamento de Engenharia Química, Universidade Federal do Paraná - UFPR.

MADAN, M.; VASUDEVAN, P.; SHARMA, S. Cultivation of Pleurotus sajor-caju on different wastes. Biological Wastes, v. 22, n. 4, p. 241-250, 1987. 
ORTEGA, G. M.; MARTÍNEZ, E. O.; BETANCOURT, D.; GONZÁLEZ, A. E. Bioconversion of sugar cane crop residues with white-rot fungi Pleurotus sp. World Journal of Microbiology and Biotechnology, v. 8, n. 4, p. 402-405, 1992.

RAJARATHNAM, S.; BANO, Z. Pleurotus mushrooms. Part III. Biotransformations of natural lignocellulosic wastes: commercial applications and implications. Critical Reviews in Food Science and Nutrition, v. 28, n. 1, p. 31-113, 1989.

RORABACHER, D. B. Statistical treatment for rejection of deviant values: critical values of Dixon's "Q" parameter and related subrange ratios at the 95\% confidence level. Analytical Chemistry, v. 63, n. 2, p. 139-146, 1991.

SANTOS, V. M. C. S. Contribuição ao estudo da produção de Pleurotus spp. em resíduos lignocelulósicos. Florianópolis, 2000. 149p. Dissertação - (Mestrado em Engenharia Química), Departamento de Engenharia Química, Universidade Federal de Santa Catarina - UFSC.

SILVA, D. J. Análise de alimentos: métodos químicos e biológicos. Viçosa: Universidade Federal de Viçosa, 1981.

SILVEIRA, M. L. L.; WISBECK, E.; NINOW, J. L.; GERN, R. M. M.; FURLAN, S. A. Pleurotus cultivation in submerged culture and nutricional value of fruit bodies cultivated in solid culture. In: LARROCHE, C.; PANDEY, A.; DUSSAP, C. G. (EDs.). Current Topics on Bioprocesses in Food Industry. New Delhi: Asiatech Publishers, 2006. Cap. 16, p. 197-203.
STÖLSER, S.; GRABBE, K. Mechanisms of substrate selectivity in the cultivation of edible fungi. In: MAHER, M. J. (Ed.). Science and cultivation of edible fungi. Rotterdam: Balkema, 1991. v. 1, p. 141-146.

STURION, G. L. Utilização da folha de bananeira como substrato para o cultivo de cogumelos comestíveis (Pleurotus spp.). Piracicaba, 1994. 147p. Dissertação - (Mestrado em Ciência e Tecnologia de Alimentos), Escola Superior de Agricultura Luiz de Queiroz, Universidade de São Paulo - USP.

TUOR, U.; WINTERHALTER, K.; FIECHTER, A. Enzymes of whiterot fungi involved in lignin degradation and ecological determinants for wood decay. Journal of Biotechnology, v. 41, n. 1, p. 1-17, 1995.

VILLAS-BÔAS, S. G.; ESPOSITO, E.; MITCHELL, D. A. Microbial conversion of lignocellulosic residues for production of animal feeds. Animal Feed Science and Technology, v. 98, n. 1-2, p. 1-12, 2002.

WISBECK, E.; ROBERT, A. P.; FURLAN, S. A. Avaliação da produção de agentes antimicrobianos por fungos do gênero Pleurotus. Health and Environment Journal, v. 3, n. 2, p. 7-10, 2002.

ZADRAZIL, F.; PUNIYA, A. K. Studies on the effect of particle size on solid state fermentation of sugarcane bagasse into animal feed using white-rot fungi. Bioresource Technology, v. 54, n. 1, p. 85-87, 1995. 